AIRESEAFCH MAIUUACTURING COMPANY OF ARIZONA

QUALITY CONTROL GENERAL INSTRUCEION

\section{NOTICE}

\section{PORTIONS}

has been rep

copy to permit the broadestpossible availe
QCGI NO. $23^{\circ}$ ISSUEN: $9-3:-75$

$\checkmark$ REVISTD: 11-19-PAGE 1 OP 5

GUBJECT Pbildeblity Assurance Program supplement

For ERDA-Brayton Isotope Power System

(BIPS)

\title{
1.0 PUFPOSE
}

1.1 To assure compliance with ERDA Quality Assurance Soectfication Sis-1, Rev. 1. The requirements of that specification are to be consiaered "quality requirements" in tha sense in which that term appears in various jntenal hipesearch procedures, such as quality control procedure $(9.0 .2$ 2.16, paragraphs $1.1,4.1 .2$, etc.

NOTE: Compliance with Gis-l in its entirety is racuired and is generally accomplished by Aikesearch's sincle standa. Quality control system as desaribec? in the Geneal puid. I Program Plan, QC-043, Rev. 4. In the event cf conflict between this QCGI and QC-048, Pev. 4, thig QCGI shail teke precedence.

2.0 DETAILED INSTRUCTIONS

2.1 Eraining (sas-1, para. 2.4). General complinge rith th.. requirement is accomplishad by:

(a) Quality control proceduce i2.C.P.) 1.15, procasumal Control, Work Instructions, and Qualification of personnel

2.2 Certification of Personel ( pliance with this requirencent is accomplished bs:

(a) Q.C.P. 1.15, Procedural Control, work Inetructions, nat Qualification of personnel

(b) 2.C.P. 7.0, Qualification of ivondestructive Tastanc Personne1

2.2.1 Whenever quaitication oE pacsonnez is laguruet methods or processos cther than thosa ovyr Q.C.P. 7.0, wuch gualdfication mall be rochl and

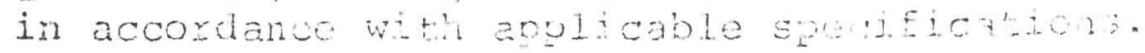




\section{DISCLAIMER}

This report was prepared as an account of work sponsored by an agency of the United States Government. Neither the United States Government nor any agency Thereof, nor any of their employees, makes any warranty, express or implied, or assumes any legal liability or responsibility for the accuracy, completeness, or usefulness of any information, apparatus, product, or process disclosed, or represents that its use would not infringe privately owned rights. Reference herein to any specific commercial product, process, or service by trade name, trademark, manufacturer, or otherwise does not necessarily constitute or imply its endorsement, recommendation, or favoring by the United States Government or any agency thereof. The views and opinions of authors expressed herein do not necessarily state or reflect those of the United States Government or any agency thereof. 


\section{DISCLAIMER}

Portions of this document may be illegible in electronic image products. Images are produced from the best available original document. 


\subsection{DETAILED INSTRUCTIONS (Continued)}

2.3 Quality Reviews (SNS-1, Para. 3.2) General compliance with this requirenent is accomplished by:

(a) Q.C.P. 1.50, Quality Assurance Engineering

(b) Q.C.P. 13.1, Manufacturing Quality Engineering - Process Control

(c) Q.C.P. 13.2, Manufacturing Quality Engineering - Quality Planning

(d) Q.C.P. 13.3, Inspection Instructions - Manufacturing And Procurement Quality Assurance

2.3.1 In complying with the above procedures particular attention shall be paid to assuring that:

(a) The design lends itself to tosting at various levels of assembly and the testing process is adcuuate to yieid the required information without degradation of the hardware quality.

(b) Processes specificd are rell establishod and nrovon, or that qualification of them is provided.

(c) cleanliness and contarnination specifications for mato. and processes are consistent with design refuitremon:s and provide assurance that contamination at any point the program cannot affect use or performance.

\subsection{Traceability And Idontification (SNS-1, Para. Á.) Gencral} compliance with this requirement is accomplished by:

(a) Operational procedure (O.P.) 4,100, Identification for Traceability Requirements

(b) Oporating Instruction (O.I.), 3.1, Identification Eor Traceability Requjements.

2.5 Purchase Order peruiromonts (S.S-1, Para. 5.3.2) Gonra! compliance with this requiroment is accomplished by:

(a) Q.C.P, 2.16, Definition of Quality Requircments on Requisitioning/Purchasing Documents

(b) Document 72-8599 Supplemental purchase order Cotitions 
'2.0 DETAILED INSTRUCTIONS (Continued)

2.5.1 Particular attention shall be paid to assuring that the procurement documents contain the following provisions (when applicable) of SNS-1, para. 5.3.2.c: item (1), Changes; item (5), Age Control and Life Limited Products; itern (14), Parts and Processes Involving Proprietary Information.

2.6 Receiving Inspection/Control of Procured Articles And Materi ment is accomplished by:

(a) Q.C.P. 2.3, Source Inspection - Product Accoviance at Source

(b) Q.C.P. 2.10, Receiving Inspection

(c) Q.C.P. 2.11, Inspection of Government Furnished Pioperty (GFP)

(d) Q.C.P. 2.12, Pre-Inspection Review Of Incoming llaterial

(e) Q.C.P. 2.13, Raw Stock, Raw Castings, And Paw rongings Inspection

2.6.1 Receiving inspection personnel shall pay particular attention to assuring compliance with Sis-1, para. 5.6. (7), Age Control (when applicable), ard 5.5. (9), Random Chemical Analysis and Physical Tests.

2.7 Process Qualification (SNG-1, Para. 6.4) General compliance with tiris requirement is accomplished by:

(a) AiResearch Material' And Process Specification Index. Each specification contains the requirements for qualification of the process and periodic verification of continued conformance. Specifications PC-5001 and FP-5045 are cited as typical.

2.7.1 Basic changes (i.e., changes which would alter the characteristics - physical, chomeal, motajlurgical, etc. -- of the parts) to processes and,or eminment shall not be made without notification to ERDA.

2.8 Cleanliness And Contamination Control. (SNS-1, Fara. 6.5) General compliance with this requirement is accomplisped by:

(a) Product cleaning specifications, listed on page 5 of th AiResearch Material And process Specification Index. 
QCGI NO. 137

PAGE 4 OF 5

2.0 DETAILED INSTRUCTIONS (Continued)

2.8 (b) O.P. 4.39, protective Closures and Material Handing

(c) Facilities cleanliness is assured by the specification for Janitorial Sub-Contract, especially pages $\mathrm{C}-4, \mathrm{C}-5$, and $\mathrm{C}-6$.

2.9 Workmanshio Standards (SPS-1, Para. 6.7) General compliance with this requirement is accomplisher by:

(a) O.P. 4.25, Quality Standards

(b) Q.C.P. 1.18, Preparation, Publication, and Revision of Quality Standaras.

2.10 Contractor Quality Assurance Actions (Sis-1, Para. 7.2.5)

(a) Q.C.P. 4.0, Assembly Surveillance

*(b) Q.C.P. 4.1, Preparation of Power Gystems Asembly Inspection Instructions and Assembly Traveler.

(c) Q.C.P. 6.0, Inspection Surveillance of Acceptanca Tests and Qualification Tests.

2.10.1. In complying with the abov procedures particular attention shall be paid pick to testing to:

(a) Verify that applicablo inspection and test documents are complete, unambiguous and available.

(b) Insure that requirements for selection and control of articles to be tested have been implemented.

(c) Verify that articles are identified.

(d) Verify configuration of articles.

(e) Verify that test equipment, inchuding any ground suoport equipment (Gs) required, is as specified in tie "rest Instructions (TI). 


\subsection{DETAILED INSTRUCTIONS (Continued)}

2.10 .1 (f) Verify that test eruipment is calibrated and such calibration will be effective and sustained during the test period.

2.10.2 During testing, particular attention shall be paid to:

(a) Insure that testing is accomolished in accordance vith test specifications and procedures.

(b) Insure accurate and complote recording of data and tost. results.

(c) Document rework, repair or modificntzo occurring during the test operation.

(d) Document nonconformances and particupate in their dispositions.

2.10.3 Subsequent to testing, particular ittention, shall be paid to:

(a) Insire proper disposition of ar icles.

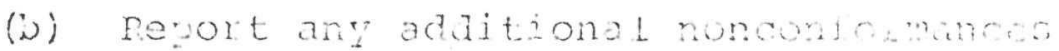
and participate in the di pootions.

(c) Insure that remedial and prevertivo

action has beon accomplishod ralacio to nonconformazce.

(d) Verify that tost results and renors are accurate, complete: and traceanle to the tested articlos.

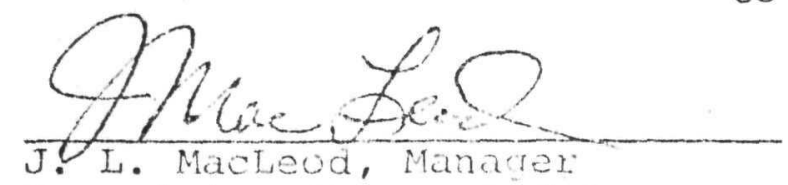

Propulsion Englne And power Systems Quality Assurance

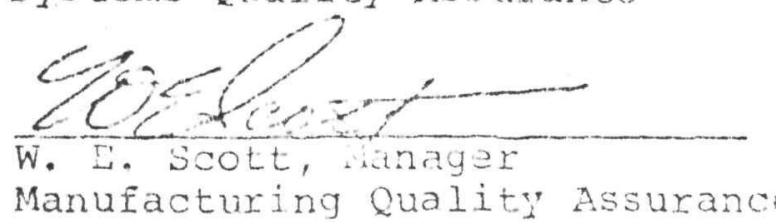

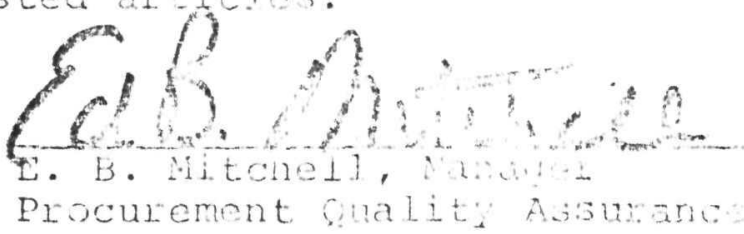

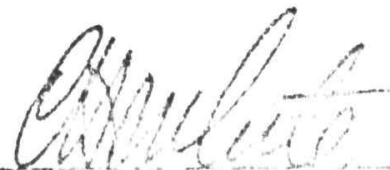

C. II. hilo, Sutrivisor Quality planning

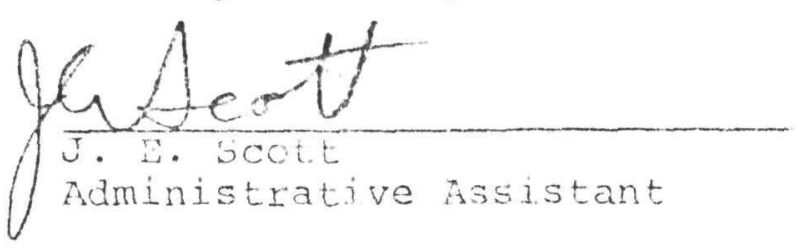

* Denotes revision. 